\title{
Authors, Archaeology, and Arguments: Evidence and Models for Early Roman Politics
}

\begin{abstract}
Ancient history begins and ends with the ancient evidence. The evidence represents not only the foundation of the discipline, but the material out of which any argument must be built, and it is not possible to go further than it allows. This is part of the reason why the nature and value of the evidence for early Rome have long been, and remain, matters of considerable and sometimes contentious debate. The best evidence, simply because it is contemporary, is arguably the archaeological, but the sorts of questions that archaeological evidence can answer are often of little help when it comes to matters such as the politics and political structures of early Rome, which are the focus of this collection. For such matters, it is still necessary to work with the literary evidence. However, since the historical value of the literary evidence is so hotly contested, the uses to which that evidence is put and the conclusions that are drawn from it inevitably vary considerably. Despite more than a century of research, there is still nothing even remotely resembling a consensus on how the literary sources should best be handled. This paper explores some of the problems with the evidence for early Rome, considers something of the limits and uses of that evidence, as well as introduces the contributions that make up this collection of studies on power and politics in early Rome.
\end{abstract}

The city of Rome was first ruled by reges. ${ }^{1}$ Liberty and the consulship were established by L. Brutus. That is the succinct formulation of Tacitus, but he was unique only in his brevity. ${ }^{2}$ The tradition of the expulsion of the Tarquins and the creation of the Roman Republic was a very well established one, as the coin depicted below illustrates. The image on the reverse shows L. Brutus holding the new office of consul, while a bust of Liberty - and, along with it, the understood absence of monarchic rule can be seen on the obverse. The coin therefore advertises the very same events and ideas found in those two brief sentences of Tacitus. It also serves, conveniently enough, to illustrate some of the themes and topics with which this collection of papers is concerned - viz. the evolution of politics and power in Rome -, as well as some of the methodological

1 'Rex' is usually translated as 'king'; that word, however, comes with a considerable amount of anachronistic baggage, and so has been avoided here.

2 Tac. Ann. 1.1: urbem Romam a principio reges habuere; libertatem et consulatum L. Brutus instituit. 

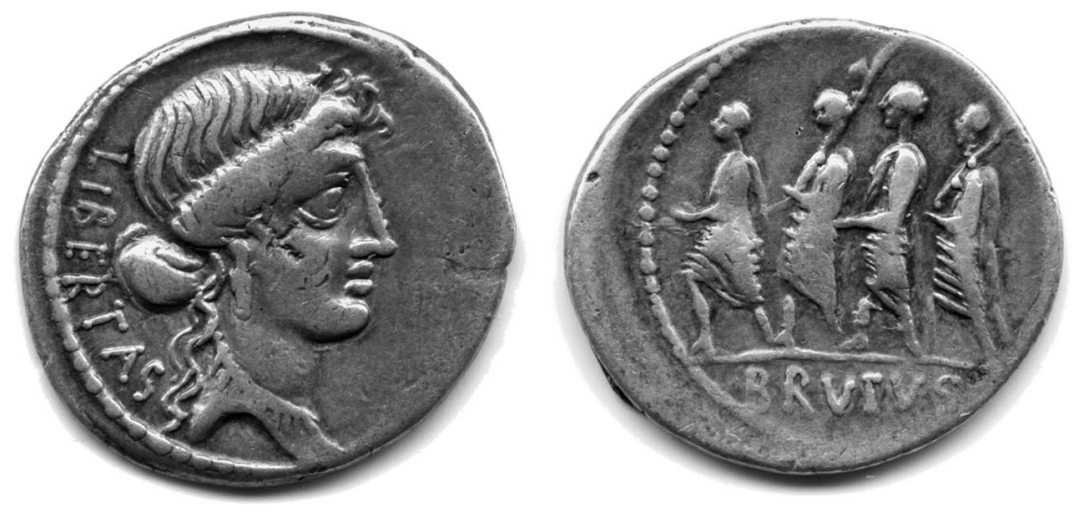

$R R C$ 433/1. Struck silver Denarius. 54 BC. Marcus lunius Brutus (moneyer). Rome (mint).

Gale Collection, ACANS 07GR433/1.

Australian Centre for Ancient Numismatic Studies, Macquarie University. Used with permission.

problems with which anyone who works on the history of early Rome must deal.

The Romans believed that their city was ruled by reges, and archaeological evidence is generally thought to have confirmed the presence of reges at Rome, whatever the actual status and powers of those enigmatic figures may have been. ${ }^{3}$ At the end of the sixth century $\mathrm{BC}$ - or so the Romans believed - the rule of the reges was brought to an end and the Republic was established. Rome was henceforth supposedly led by consuls. Although the consuls were said to have had the same powers, dress, and insignia as the reges, they were also said to have held office for just one year (after which they returned to private life), and always to have shared their powers equally with a colleague. The simple fact that power was shared and held only briefly, it was believed, ensured that Rome was not only free - something which the very expulsion of the last rex, who was said to have been an abusive tyrant, had already helped to establish but would also remain so. ${ }^{4}$

3 The most famous piece of evidence is the cippus from beneath the Lapis Niger, on which the word recei appears. The cippus was discovered by G. Boni in 1899, by chance, just after the appearance of the first volume of E. Pais' famous Storia di Roma (1898), and thus disproved Pais' argument that Rome's reges never existed; on the discovery, see Sisani (2004) 62-3. A small bucchero shard with the word 'rex' inscribed on it has also been found in the Regia and is usually dated to the fourth phase of that building, according to Brown's reconstruction (see Cristofani [1990] 22-3). However, it is uncertain whether the rex referred to in either of these inscriptions was the actual rex (i.e. the 'king') or another magistrate or priest, such as, most obviously, the rex sacrorum.

4 Livy 2.1.7-8: libertatis autem originem inde magis quia annuum imperium consulare factum est quam quod deminutum quicquam sit ex regia potestate numeres. omnia iura, omnia 
The man who was believed to have been crucial in the expulsion of the reges, the setting up of the new Republic, and one of the first to hold the new office of consul was of course L. Iunius Brutus. ${ }^{5} \mathrm{He}$ can be seen very clearly on the reverse of that coin. He is the tallest of the figures, and comes third in the procession. He is depicted wearing a toga, while in front of him, and behind him, are lictors, easily recognisable by the fasces - the bundles of rods with an axe that symbolised the powers of the consuls which they carry. On the left, at the head of the procession, is a herald (accensus). The image is specifically of L. Iunius Brutus as Rome's first consul. This is the very first year of the republican period; that is, on the traditional chronology, 509 BC.

The image therefore evokes the two themes of this collection of papers: power and politics in early Rome. But, more significantly for the present discussion, it also raises some of the many methodological problems that not only make the study of early Rome so challenging, but also an 'ideal school of historical method', as A. Momigliano put it many years ago. ${ }^{6}$ While the coin depicts something of the alleged events of 509 BC, it was actually struck some four and a half centuries later, in $54 \mathrm{BC}$, and in radically different circumstances. Rome in the first century $\mathrm{BC}$ was vastly different from Rome in the late sixth, even if the image on the coin does little to convey that. ${ }^{7}$ The coin was, moreover, issued by a man M. Iunius Brutus - who claimed to be descended from the great founder of the Republic. While it was common practice for Roman nobles to advertise the achievements of their ancestors, and indeed figures from such ancient times had already been depicted on coinage by others (for example, an image of the rex Ancus Marcius had been put on a coin issued by a member of the Marcii, L. Marcius Philippus, as recently as $56 \mathrm{BC}){ }^{8}$ there may be something more specific involved in this instance. It has been argued that 'the issue forms part of a pattern of consistent opposition to Pompey's real or supposed intentions of achieving sole rule. ${ }^{9}$ On this

insignia primi consules tenuere; 4.3.9: consules in locum regum successisse nec aut iuris aut maiestatis quicquam habere quod non in regibus ante fuerit; note 2.7.5-6 and 2.18.8 on collegiality; cf. also Sall. Cat. 6.7; Cic. Rep. 2.56; Dion. Hal. Ant. Rom. 4.73.4, 4.74.2-3, 5.12.3, 5.19.1; Val. Max. 4.1.1; Flor. 1.9.2; Eutrop. 1.9.

5 Brutus is the mostly widely attested of the first two consuls; most sources say that his colleague was L. Tarquinius Collatinus (see Broughton [1951] 1-3), but Polyb. 3.22.1 thought that his colleague was M. Horatius. Some sources claim that Valerius Publicola was one of the first consuls: Cic. Flacc. 25; Val. Max. 2.4.5, 4.4.1; Plin. HN 36.112.

6 Momigliano (1963) 108.

7 On the coin and its date, see Crawford (1974) 455-6. The 'little' that the image on the coin includes to show something of the differences between Rome in the late sixth century and Rome in the first is the axe in the fasces that the lictors carry. The axes were said to have been removed by P. Valerius Publicola: Cic. Rep. 2.55; Dion. Hal. Ant. Rom. 5.19.3; Val. Max. 4.1.1; Plut. Publ. 10.5; etc.

8 RRC 425/1.

9 Crawford (1974) 455. 
interpretation, the image on M. Brutus' coin was designed to play a precise political role, and to send out a clear message about the Republic, republican liberty, and the fate of would-be kings. M. Brutus would, it is implied, live up to the celebrated achievements of his ancestor. ${ }^{10}$

As M. Brutus' coinage shows, even the events of the remote past could play a part in the political struggles of much later times. While Roman historians such as Livy could lament the loss of records from Rome's earliest history and comment on the difficulties involved in writing about Rome's distant past, ${ }^{11}$ such concerns were unlikely to trouble the Roman statesman interested only in exploiting the traditions of the past for his own immediate political purposes. Indeed, the uncertainty and flexibility of the tradition of early Roman history meant that such purposes could easily take precedence over any interest in historical veracity. It is not at all surprising that Livy noted that funeral speeches and tituli contained incorrect information about the achievements of earlier statesmen. ${ }^{12}$ The traditions of the past were not only fluid, they were also important 'symbolic capital' for Rome's nobility. ${ }^{13}$ As such, they always remained relevant and useful, and this inevitably meant that they were always prone to being distorted and modified.

Even apart from the question of manipulation at the hands of later statesmen (a problem the scale of which is, perhaps not surprisingly, a matter of some disagreement among scholars), there are other good reasons to question the value of evidence like M. Brutus' coin. Did consuls in the late sixth century BC actually wear togas? Did they have lictors and other attendants? If they did, did those lictors carry fasces? Was the consulship already associated with liberty in the late sixth century? Indeed, did the consulship even exist at that time? That is, does the image on the coin reflect anything at all of the actual historical realities of Rome in the late sixth century, or does it only show what some Romans in the mid-first century may have believed about that earlier period? These questions have been variously answered, both directly and indirectly, in modern scholarship. More can easily be added. How did the monarchy come to an end? Was it following a largely peaceful revolution, as the Romans supposed, or were the events more violent in nature, as some have contemplated and as archaeological evidence may possibly suggest? Or was there even a revolution at all, or instead perhaps some longer

Cf. Cic. Phil. 2.25-6. As indeed he claimed he did, when he murdered Iulius Caesar (see $R R C 508 / 3$, on the reverse of which a freedman's cap is depicted between two daggers).

11 See Livy 6.1 .2 on the loss of records; on the difficulties involved in writing about the past, see Forsythe (1999) 22-39 for references to the relevant evidence in books 1-10 of Livy's work.

12 Livy 8.40.3-5; so too Cic. Brut. 62.

13 On the idea of family traditions as 'symbolic capital' see, e.g., Flaig (2003), esp. 49-68; Hölkeskamp (2010) 107-24; Jones (2016). 
process of evolution? ${ }^{14}$ As for M. Brutus, was he even descended from L. Brutus, as he claimed? The answer to that question was clearly contested in antiquity, ${ }^{15}$ and that says much about the role the events of the past could play in the politics of much later times. The past was always relevant, and it was always being reconstituted and reinterpreted in the (terms of the) present, as the doubtless anachronistic image on the coin shows.

When it comes to the writing of history at Rome, the situation is little improved from the circumstances of the coin. It may be a commonplace observation, but it is so for very good reasons: no one appears to have written history at Rome until sometime in the late third century BC. Several Greeks, it is true, had written about Rome, even as early as the fifth century, but those early writers clearly possessed very little, if any, real knowledge about the city and Rome was long of limited interest to Greek historians. ${ }^{16}$ The first Roman to write a history of Rome was a man called Q. Fabius Pictor, a senator active during the great war with Hannibal. ${ }^{17}$ How did Pictor know about the events of Rome's distant (and even not so distant) past? What were his sources? ${ }^{18}$ How did he use those sources to produce a narrative of Rome's past? What sort of narrative did he produce? ${ }^{19}$ Answers to these questions are plentiful, but they are all necessarily hypotheses, since Pictor's work has been lost. No one can read it today, but even if someone could, it may not necessarily make all that much difference: Pictor may not have revealed his sources or said anything about his methods, as it was not required of the historians of antiquity to say where they got their material or to explain how they handled it. ${ }^{20}$

Early writers such as Hellanicus of Lesbos and Damastes of Sigeum had discussed Rome's origins (Dion. Hal. Ant. Rom. 1.72.2), but appear to have known little (cf., e.g., Gabba [1991] 12-13); Pliny the Elder said that Theophrastus was the first to write about Rome with any diligence ( $H N 3.57$ ), while Dionysius knew of no one before Hieronymus of Cardia who had written on the history of early Rome (Ant. Rom. 1.6.1). Timaeus of Tauromenium may have visited Lavinium (Dion. Hal. Ant. Rom. 1.67.4); it is not impossible that he went to Rome too (see Polyb. 12.4b: Timaeus wrote about the Roman ritual of the October Horse).

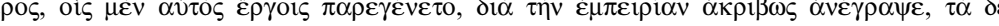

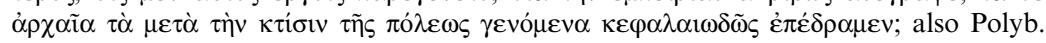
1.14.1-3, 1.15.12, on the partisan nature of Pictor's work. It is not even known for certain if his account was annalistic in structure. For a recent discussion, see Bispham and Cornell (2013).

20 It is worth noting that some historians, such as Livy, do from time to time say where they got their material; in Livy's case, it is striking (by modern standards, at least) that he was by and large happy just to follow what his predecessors had said. There is no evidence that he visited archives, consulted priestly records, tracked down documents and inscriptions, or went to the households of noble families for the purposes of research, that is, that he did any of the things 
To make matters worse, lost too are the writings of just about all of Rome's subsequent historians, and of those there was a great crowd. ${ }^{21}$ The earliest extant historiographical material comes - just like the coin - from the mid-first century BC. Even if Pictor's account of Rome's earliest history had been reliable and veracious (and it is impossible to know if it was, although it is reasonable to ask how it possibly could have been), what had happened to it in that intervening century and a half? That question is not easily answered, but there is some evidence, and it is not encouraging.

Think of M. Brutus, the issuer of the coin, and his use of the past and the debate about his ancestry. Why should the historical writings of Roman statesmen have been immune to the same sorts of pressures? It would appear that they were not. Evidence for the debate about the ancestry of M. Brutus was clearly found, and indeed is still to be found, in the writings of historians. ${ }^{22}$ And Livy, who was certainly in a position to judge, noted that the historian Licinius Macer was unreliable when he wrote about his own family. ${ }^{23}$

The idea that Rome's historians were actually able to modify their material has often been denied, however, and sometimes vigorously so. The beliefs of T. J. Cornell have been especially influential, and Cornell has certainly stated his position very clearly: ${ }^{24}$

Roman annalists were not in a position to impose a fraudulent version of Rome's history on their contemporaries and on succeeding generations of historians. The main outline of political and military events was a matter of public knowledge in the later Republic; it was clearly set out in the works of historians such as Fabius Pictor, Cato the Censor, and L. Calpurnius Piso Frugi, men who had themselves made history and knew what they were talking about... It is simply inconceivable that relatively late writers such as Valerius Antias could have departed radically from the received tradition and hoped to get away with it.

that Fabius Pictor is often supposed to have done. Pictor too may have drawn on earlier writings; see Bispham and Cornell (2013) 174-5. Polybius, who was exceptional, certainly visited archives, and he found inscriptions, most famously Rome's treaties with Carthage; his handling of that material suggests that it was newly discovered (and by him), and that is very telling; see Polyb. 3.22-6.

Cf. Livy praef. 3: tanta scriptorum turba.

See n. 15 above; it was evidently a long-standing issue (Plutarch refers to the work of Posidonius), although the murder of Caesar clearly gave it new life.

23 Livy 7.9.5. This is rejected by Smith (2011) 28-31. Smith's argument is essentially that the evidence does not support Livy's view; but Macer's work is lost, and Smith's assessment is only based on a few passages of Livy, where Livy happens to have mentioned Macer; in contrast, Livy's view will have been based on his reading of Macer's work (although that is effectively denied by Smith; in his discussion of 7.9.3-6, Smith says: 'this is the passage on which the whole argument for Licinius' false insertion of his family into the history of Rome is based' [our emphasis], but that is hardly the case, nor is that even Livy's precise charge).

24 Cornell (2005) 49. 
These comments were first published in 1986, and they have been taken up and repeated by many. Indeed, they seem to make sense. Rome's great families were competing for prestige within a specific context, and so certain rules arguably should have applied. If the details of Rome's history were mutable, and each gens was able to fabricate events, offices, and honours wholesale, then those events, offices, and honours should, presumably, have lost their importance. Why should, or would, anyone have cared about clear fictions?

Equally, however, doubts about some of Cornell's views were expressed even in the very same book in which these comments appeared. ${ }^{25}$ And even amongst proponents of Cornell's stance, there is considerable disagreement about what constitutes this supposedly stable 'main outline of political and military events'. It is worth adding as well that the current environment of 'post-truth politics', 'fake news', and 'alternative facts' has demonstrated all too clearly that there exists a number of contexts in which 'clear fictions' can be considered useful political currency. Despite natural assumptions to the contrary, a solid connection to 'the truth' does not seem to be a necessary requirement in all political discourse. Veracity can never be taken for granted, while dishonesty can be surprisingly blatant, even when the details are readily verifiable (which they were not in antiquity). Moreover, even if the 'main outline of political and military events' really was 'a matter of public knowledge', which is far from certain, why should the members of Rome's nobility have been concerned to weed out any inventions or lies, even more so if they did not impact on them directly? How would they have tried to do this? And would any such attempts have had any effect, even if they had been made? The environment of today is, again, suggestive, and it does nothing to engender any confidence. And, besides, even if the main narrative of early Roman history had somehow been 'stable' and had generally been accepted by Rome's nobility, that does not mean that it was necessarily reliable to begin with. While it can be argued, as Cornell does, that Rome's nobles may have worked to keep each other honest and rein in the more excessive claims, it is reasonable to assume that they would, in general, have only propagated a view of the past that benefitted them as a whole.

As for Valerius Antias, the author singled out by Cornell, Livy was certainly clear in his assessment of him: Antias was unreliable. What caught Livy's attention above all else were Antias' tallies, of casualties in battle, of war machines, and the like. Antias clearly exaggerated, and Livy could prove this. ${ }^{26}$ To be able to maintain, therefore, that Antias could not depart radically from the received tradition and hope to get away with it,

25 Raaflaub (2005) 24-6 (and Raaflaub's addendum for the second edition, 26-31); von Ungern-Sternberg (2005) 81-2.

26 Livy 26.49.3: si Valerium Antiatem, maiorum scorpionum sex milia, minorum tredecim milia - adeo nullus mentiendi modus est; 30.19.11; 33.10.8: see n. 28 below; 36.19.11-12 (12: si Antiati Valerio credamus); 36.38.5-7 (7: ubi ut in numero scriptori parum fidei sit, 
Cornell has to make a distinction, between unimportant or insignificant (that is, acceptable) and radical (that is, unacceptable) departures from the received tradition, and to suppose that the inflation of numbers only constitutes an unimportant and so acceptable departure (although Livy, it seems, would not have agreed with that). ${ }^{27}$ But is it possible to maintain that such a distinction was also made by Antias himself? Is it possible to have confidence that, as he wrote his history, Antias knew that he could claim that very large numbers of enemy soldiers had been killed in some particular battle, even one as important and comparatively recent as the battle of Cynoscephalae, ${ }^{28}$ but also that he knew that he could not, for instance, modify his account of some event by inserting some figure or giving someone a more important role, or even just devise some episode outright? ${ }^{29}$ That may seem to be a different order of things from inflating a few numbers, but did it to Antias? And, even if it did, is there any reason to believe that he would have cared $?^{30}$ What were his priorities? In the end, it is only his judgement and his integrity that matter, and that applies to all of Rome's historians, who - in the absence of evidence - must necessarily be supposed to have had more or less the same level of understanding and honesty. ${ }^{31}$

There is a further problem that needs to be taken into account which is immediately relevant in this context: the amount of material that Rome's historians produced dramatically increased over time. The first histories of

quia in augendo eo non alius intemperantior est); 38.23.8; 39.41.5-6 (6: si Antiati Valerio credere libet); 45.43 .8 .

27 Cornell (2005) 58-9 and (1995) 17-18 frames things differently; the distinction he makes is between 'structural facts' and 'narrative superstructure'. The first was sacrosanct, the latter open to manipulation and modification.

28 Livy 33.10.7-10: caesa eo die octo milia hostium, <quinque> capta; ex victoribus septingenti ferme ceciderunt. si Valerio qui credat omnium rerum immodice numerum augenti, quadraginta milia hostium eo die sunt caesa, capta-ibi modestius mendacium est - quinque milia septingenti, signa militaria ducenta undequinquaginta. Claudius quoque duo et triginta milia hostium caesa scribit, capta quattuor milia et trecentos. nos non minimo potissimum numero credidimus sed Polybium secuti sumus, non incertum auctorem cum omnium Romanarum rerum tum praecipue in Graecia gestarum.

29 Note, however, Livy 32.6.5-8, 37.48, 42.11 .1 (plurium annales, et quibus credidisse malis,... tradunt), and 44.13.12-14 for evidence of problems in Antias' work of a kind different from merely exaggerated numbers. Cornell singles out Antias because he has long been suspected of doing the sort of thing Livy implies Macer did, i.e., in Antias' case, glorifying the Valerii; see, e.g., Ogilvie (1965) 14; Wiseman (1979) 113-17; Wiseman (1998) 75-89; Richardson (2014).

30 Note the comments of Polybius about the need for historians to tell the truth (1.14); the fact that Polybius even needed to state this is important evidence of what the usual standards and approach were.

31 Honesty, it should be noted, is a word that is only applicable in specific circumstances. An historian can only lie or be dishonest if he knows the truth (or at least what purports to be the truth) and is prepared to depart from it. Inventing, padding out, embellishing, and filling in gaps are just as likely to have been seen as plausible reconstruction. They are unlikely to have been seen as lying (which, strictly speaking, they are not in any case). And standards could be different. See, for instance, Wiseman (1979) and (1993). 
Rome were short works, perhaps never (but rarely, if ever) more than ten books in length. By the first century BC, however, that had changed significantly, and not just because later historians had more to cover. In the first century, Roman historians were able to write about the past at greater length, indeed at far greater length than their second-century predecessors.

Cato the Elder's Origines, which were likely composed in the second quarter of the second century BC, filled just seven books, and two of those appear to have been concerned only (or at least primarily) with the origins of other cities in Italy. ${ }^{32}$ Cato dealt with the beginnings of Rome, and his account evidently went as far as the middle of the second century BC. L. Calpurnius Piso, writing in the late second century, took his narrative at least as far as $146 \mathrm{BC}$, but possibly right down to his own day, and likewise needed just seven, or perhaps eight, books. ${ }^{33}$ About a century later, Livy needed 49 books to get as far as Cato had, ${ }^{34} 52$ to get to $146 \mathrm{BC}$, and 61 to reach Piso's censorship of 120 BC.

This obvious and dramatic expansion naturally raises the question of where all the extra material had come from. How were historians in the first century able to write at such greater length than their second-century predecessors? What new material did they include? (Even that question cannot easily be answered, since the works of the second century historians have been lost.) Some scholars have looked at the possibility that new sources of information may have become available; most notably, the supposed publication of the Annales Maximi by P. Mucius Scaevola has been discussed in this context, although Scaevola's publication of the work now seems unlikely. ${ }^{35}$ Scholars have also argued that individual historians were to blame. $\mathrm{Cn}$. Gellius in particular has been heavily criticised for his seemingly egregious expansion of Rome's past; he evidently covered the rape of the Sabine women (which took place in the fourth year of Romulus' reign, or so he claimed) in his second book, and he had got only as far as the events of $389 \mathrm{BC}$ by book 15, and the events of $216 \mathrm{BC}$ by book 33 (Livy, in comparison, had already reached the same events of 216 by book 23 ). ${ }^{36}$

Whether or not new sources were available to him, it is possible to envisage Gellius expanding his narrative with the inclusion of lengthy speeches, by rationalising myths (as he appears to have done with the story of Cacus), ${ }^{37}$ embellishing his account with spurious detail, and perhaps

Nepos Cato 3.3.

146 BC: FRHist 9 F 41; own day: cf. Pobjoy (2013) 234, 236.

4 The last dateable fragments of the Origines refer to the trial of Ser. Sulpicius Galba (FRHist $5 \mathrm{~F}$ 104-7), covered by Livy in book 49, according to Per. 49. But Cato died in 149 or early 148 .

35 Rich (2013) 151-8. On the question of the publication of the Annales Maximi, see Frier (1999).

36 FRHist 14 F 2-3, 8, 9. See Badian (1966) 11-12; Wiseman (1979) 20-6; Briscoe (2013) 253-5 for criticism.

37 FRHist $14 \mathrm{~F} 17$. 
even by inventing events and whole episodes outright. He may also have included greater amounts of antiquarian material than his predecessors had done. In the first century BC, Cicero commented that the writings of the antiquarian Varro, which were certainly extensive, had 'revealed the age of our native city, the chronology of its history, the laws of its religion and its priesthood, its civil and its military institutions, the topography of its districts and its sites, the terminology, classification and moral and rational basis of all our religious and secular institutions. ${ }^{38}$ The inclusion of material of this kind may have helped Gellius to write at the length he did, ${ }^{39}$ although it is unlikely that this alone can explain the size of his work. Antiquarian material, after all, is not usually argued to make up much of Livy's account, and Livy certainly wrote at considerable length, even if he could not match Gellius. The fundamental problem, therefore, remains. Rome's first historians, who are often presumed to have had access to material from the regal period and the early Republic, covered the early history of their city in an extremely succinct and economical manner, while the origin(s) of the vast quantities of additional material that was included in the works of later historians remain(s) unknown.

All these problems - and a good many more - have long been discussed, and many different solutions to them have been put forward over the years. These solutions have, in turn, significantly affected the methods and reconstructions of historians working on early Rome. Something of the range of different approaches and arguments comes through in R. T. Ridley's contribution to this collection, in which the history of the scholarly debate about Lars Porsenna of Clusium is traced. Ridley's discussion shows as well that that debate has not always been evolutionary in nature: while some approaches have fallen out of favour, and some new methods have been developed, a good number have simply endured, sometimes for better and sometimes for worse. The different approaches and arguments that can be found throughout this collection will similarly reveal something of the range of views that exist (and, as will be clear, not all accord with the ones put forward in this introductory discussion). What these many differences show is both the extent of the problems and the robustness of the debate. Under such circumstances, the presence of incompatible views is not something to be questioned or quashed, as somehow undermining the coherence of the collection, but is instead something to be emphasised at the outset.

The study of Rome's earliest history has been put on an entirely new footing in recent years, thanks to the results of archaeological work that

38 tu aetatem patriae, tu discriptiones temporum, tu sacrorum iura, tu sacerdotum, tu domesticam, tu bellicam disciplinam, tu sedem regionum, locorum, tu omnium divinarum humanarumque rerum nomina, genera, officia, causas aperuisti... Cic. Acad. post. 1.9. Trans. Rackham.

39 Cf., for instance, FRHist 14 F 12 on the alphabet, F 14 on the invention of mining and smelting gold and medicine too, or F 15 on the invention of weights and measures. 
has been, and is still being, carried out in and around the city of Rome, as well as further afield. It may therefore perhaps come as a surprise that the impact of this work is hardly to be felt in this collection of papers (although see C. J. Smith's closing remarks for some thoughts about the more general significance of various archaeological discoveries). Part of the explanation for this is that many of the papers focus on periods for which the archaeological record is still emerging: the fifth and fourth centuries in particular, and later still. Although recent work at Gabii and other central Italian sites is beginning to reshape the way in which the early and middle republican periods are understood, ${ }^{40}$ the bulk of the archaeological evidence discovered so far is still predominantly from the archaic period. Another part of the explanation for the lack of direct engagement with the archaeological evidence is also the focus of the collection, which is politics, a subject to which those recent discoveries are able to contribute very little directly. While fortifications can hint at social and political limits, pottery finds can suggest economic interaction, and monumental temples can say something about the mobilisation and control of labour and the use of resources, the study of early Rome's political history must still rely almost exclusively on the literary evidence.

This does not mean, however, that archaeological work is simply irrelevant to the present discussion. The most immediate significance of recent work in this field is the way in which it has stimulated the debate about whether or not and, if so, how the literary evidence can be used in conjunction with archaeological evidence, and the effect this debate has had on the way in which both archaeological and literary evidence are used in their own right. In all of this, the extremely controversial work of A. Carandini is central. Although both polarising and provocative, Carandini's impact on the study of early Rome and early Roman archaeology has been profound. While many of his interpretations have rightly been questioned, if not simply rejected out of hand, his longstanding influence on, and authority over, the archaeological work conducted in and around the city of Rome have meant that many debates have had to begin with his assertions and have had to engage with his unique approach. Carandini's position is ultimately that the literary and archaeological evidence can simply be used together, even for Rome's earliest history. Thus, it is supposed, the literary evidence contains accurate information, even about the very beginnings of Rome - a supposition which is, in turn, supposedly supported by the archaeological evidence. Although this approach is rarely taken to such extremes, in the Anglophone world at any rate, it has nonetheless played a role in fostering an extraordinary amount of optimism (and, it must be said, largely uncritical optimism) in the value of the literary evidence, at least in some quarters. ${ }^{41}$

40 See, for instance, Becker, Mogetta, and Terrenato (2009).

41 Ampolo (2013); the title of his paper alone is telling: 'Il problema delle origini di Roma rivisitato: concordismo, ipertradizionalismo acritico, contesti.' See also, 
To pick the most obvious and straightforward example: according to Livy, when Romulus founded Rome, he built a wall around the Palatine hill. ${ }^{42}$ Carandini famously found evidence during a series of excavations in the late 1980s for what he interpreted to be a wall at the foot of the Palatine hill, a wall which he dated to round about the mid-eighth century BC, which is near enough to the time Romulus supposedly founded Rome (in some accounts, at least). The literary and archaeological evidence would therefore seem to agree, and the story of Romulus' foundation of Rome is thus proved to be historical, as is Romulus himself. Although simplified, that is, in the essentials, Carandini's approach. ${ }^{43}$ And once such an approach is adopted, all those questions about how Rome's historians, who were writing more than half a millennium after the supposed foundation of Rome, could have known anything at all about Rome's origins may seem to be less important, simply because the archaeological evidence is taken to prove that they did know about Rome's origins. How they knew quickly becomes a secondary concern.

It hardly needs to be said that nothing is ever that simple. First, the approach of using the literary evidence to interpret the archaeological evidence, while at the same time effectively using the archaeological evidence to verify the literary evidence, is entirely circular. This simple reason alone explains why so many of Carandini's interpretations have found little acceptance. The debate about the historical value of the literary evidence remains as crucial, and as problematic, as ever. Second, as noted earlier, the archaeological evidence is different in nature from the literary evidence; it answers different sorts of questions; and it also suggests a very different set of circumstances from what is found in the literary evidence. When it comes to the beginnings of Rome, the archaeological evidence shows that the site of the city was inhabited by humans from at least the late Bronze Age (so the late second millennium $\mathrm{BC}$ ). ${ }^{44}$ There is, furthermore, no archaeological evidence for any 'foundation' moment, and consequently there is no archaeological evidence for any foundation date. In later times, colonies and 'planned communities' may have had foundation dates, but settlements like Rome did not, because they were not founded; they evolved and emerged over a long period of time. ${ }^{45}$ The literary evidence, however, takes it for granted that Rome was founded, and naturally offers a foundation date. This does not

e.g., Bietti Sestieri (2000); Poucet (2000) 160-81, 229-35; Wiseman (2001), (2004-2006), and (2013); Hall (2014) 119-43.

42 Livy 1.7.3: Palatium primum... muniit; also Dion. Hal. Ant. Rom. 1.87.3, 1.88 .2 and 2.37.1.

43 For an easily accessible overview of his work, see Carandini (2011). Brock and Terrenato (2016), with numerous references to further work.

The closest it is possible to get to a 'foundation' for a site like Rome is to try to trace the emergence of a distinct civic identity, which is often associated with the appearance of particular types of construction; this approach has most recently been taken by Hopkins (see Hopkins [2016]). However, there is still no proper 'foundation' per se; what is involved is simply an attempt to identify a particular (and doubtless arbitrary) moment in the wider evolution or development of an existing settlement. 
mean that the Romans really did know when their city was founded. The foundation of Rome is related in the literary evidence, and in Roman historical writing in particular, because that is what was expected; it was simply taken for granted that cities were founded and a date was therefore needed.

While the story that Rome was founded in $753 \mathrm{BC}$ is generally treated as canonical, it was in fact just one of many, and a number of well-informed Romans said that Rome had been founded at an entirely different time. Naevius, Ennius, and Sallust, for instance, put the foundation of Rome many centuries earlier, although their dates are no more based on evidence than those closer to $753 .^{46}$ The same applies to the identity of the founder. Not everyone said that it was Romulus who founded the city. ${ }^{47}$ And the location of Romulus' first walls was not fixed either. Different authors said different things about this too, and no one version is any more historical than any other; no version is based on contemporary evidence. ${ }^{48}$ So the view that Romulus founded Rome in the mid-eighth century and built walls around the Palatine hill at that time is based upon a highly selective handling of the evidence. This inevitably means that its apparent agreement with the archaeological evidence is not even a coincidence. If the archaeological evidence were different, some other combination could likely be put together and made to fit, ${ }^{49}$ and the value of the argument would be no different. It too would be a modern fantasy.

Carandini's is obviously not the only way to approach the archaeological evidence, and indeed it represents but one, and one very extreme, point of view. More nuanced approaches, in which - in contrast - the literary evidence is often barely used, if it is even used at all, have been more effective (again, see Smith's contribution in this volume for one example). Some have preferred to focus on the truly prehistoric periods of Rome's development, where there is no literary narrative to contend with, such as the late Bronze Age, which has been analysed using coring and other techniques. ${ }^{50}$ Others have explored aspects of Rome's archaeological landscape not directly discussed by the sources, such as the community's rural hinterland. ${ }^{51} \mathrm{~A}$ few have attempted to trace the development of

Serv. Auc. Aen. 1.273: Naevius et Ennius Aeneae ex filia nepotem Romulum conditorem urbis tradunt; Sall. Cat. 6.1: urbem Romam, sicuti ego accepi, condidere atque habuere initio Troiani, qui Aenea duce profugi sedibus incertis vagabantur, cumque eis Aborigines, genus hominum agreste, sine legibus, sine imperio, liberum atque solutum.

47 See Wiseman (1995) 160-8 for 61 different versions of the foundation myth of Rome. See, for instance, Dion. Hal. Ant. Rom. 2.1.4-2.1; Strabo 5.3.7; Plut. Rom. 11.1-2; cf. Wiseman (2013) 242, also for further evidence and variations.

49 Feeney (2007) 91-2: 'If the ancient tradition had fixed on 1000 as the "real" date, then these scholars would all be focusing on the exiguous human remains at Rome from around 1000 as "corroboration."

50 See, most notably, Ammerman and Filippi (2004). See Brock and Terrenato (2016) for further discussion.

51 See Fulminante (2014) and Terrenato (2001). 
archaic Rome using only the archaeological evidence, and have then compared their reconstruction with the Romans' accounts of events. Some of the results have been insightful. As J. Hopkins' recent work on monumental building in archaic Rome has demonstrated, the archaeological record can shed new light on long-studied periods. The art and architecture of the archaic city suggest that Rome was far more connected with the wider Mediterranean world than the literary sources would suggest. While Livy and Dionysius paint a picture of a Rome caught up in internal struggles, the buildings that were being erected by the community indicate a city which was part of a much wider cultural and economic dialogue. ${ }^{52}$ Rome also seems to have had a strong industrial base, most notably in pottery production, which utilised clay extracted from the Velabrum; this seems to be evidence for an economic foundation that is very different from the agrarian model espoused in ancient literature. ${ }^{53}$ And, perhaps most importantly for the present discussion, years which the literary sources depict as momentous - most notably 509 BC, in which year the reges were said to have been expelled - seem to have had little impact on the physical city itself. ${ }^{54}$ While building practices did change over time, much of the impetus behind these shifts seems to have come more from outside the community than from within it. So, while for the detailed nuances of Roman politics, and the social and political dynamics which underpin them, it will likely always remain necessary to turn to the literary sources, the archaeological record can provide valuable data and a vital counterpoint to the claims of those sources.

It is in this context of combining different types of evidence that Momigliano made his comment about early Rome being the ideal school of historical method. 'As early Rome,' he said, 'is the ideal place to combine archaeological exploration and source criticism, the study of archaic Rome remains an ideal school of historical method.' One other type of evidence for early Rome that Momigliano discussed, and one to which he assigned special importance, was the evidence of religious rites and rituals ('customs' is the specific word he used, and it is arguably a slightly loaded one). ${ }^{55}$ The justification for this is simple: Roman religion was, it is maintained, inherently conservative, and consequently did not ever really change. As a result, it is often thought that ancient religious rituals were performed in the first century $\mathrm{BC}$ largely as they had been in the sixth or seventh century BC (or even earlier still). The modern historian therefore need only study the evidence for those rituals (which

Hopkins (2016) 1-19.

Winter, Iliopoulos, and Ammerman (2009).

Hopkins (2016) 126-52.

Momigliano (1963) 98: 'There is furthermore a type of literary evidence which is in a class of its own - the evidence of religious ceremonies for the development of the city of Rome.' See p. 99 for the heading 'Evidence from Religious Customs' (our emphasis). 
usually comes from the first century $\mathrm{BC}$ ) to get some understanding of Rome in much, much earlier times.

Roman conservatism aside, that argument naturally requires that a ritual that served some particular purpose relevant to Roman society in the seventh or sixth century BC continued to be performed, essentially unchanged, by the vastly different societies, and in the vastly different circumstances, of the fourth, third, second, and first centuries BC. But why should any society continue faithfully to perform fossilised versions of ancient rituals centuries after the circumstances that had led to the emergence of those rituals had ceased to be relevant or even to exist? And at what point does an emerging and developing ritual cease to develop and become instantly fossilised? Any living religion changes and adapts to meet the needs and circumstances of the society that invents and maintains it (religion, after all, is just a tool, and humans are tool-using animals). While there is no inherent difficulty with the basic idea that a ritual could continue to be practised in some form or another long after its original purpose had been lost, it does not follow that that ritual did not subsequently have any purpose (beyond, that is, whatever purpose the preservation of a fossil may be supposed to have had). Rituals should not be thought of as fossils to be carefully preserved, but instead as tools which are repurposed to meet new needs. As such, any ritual will have been responsive to its evolving use, and will have changed accordingly. It comes as no surprise, therefore, the evidence for change in Roman religion is plentiful, and that alone undermines, if not invalidates, the approach espoused by Momigliano (and many others). ${ }^{56}$

As with the archaeological evidence, however, the baby should not be thrown out with the bathwater. Religion and ritual still form a vital category of evidence which, even if not as stable as Momigliano and others would believe, can still offer important elements of continuity, albeit of a different nature. A ritual like the Roman triumph provides a good example. Although the so-called fasti triumphales (that is, the list of the triumphs that were celebrated during Rome's long history) are a highly problematic source, they and other evidence do nonetheless suggest that the Roman triumph had existed in some form for some time (exactly how long is debated), and that it seems to have maintained a position of some importance within Rome's social, political, and religious systems down to the principate, not least because of its purported antiquity. It is clear, however (as indeed it seems to have been to the authors of our sources), that the meaning and purpose of the triumph evolved over time, and continued to do so even within what may be termed 'historical' times. Dionysius lamented that, by the late Republic, the triumph had become a 'display of wealth rather than a celebration of valour', a view which is echoed by Livy and others. ${ }^{57}$ Although the triumph's function and 
meaning may have changed over time, that does not mean that the entire ritual had altered beyond recognition. Indeed, the triumph is often thought to have featured quite a few archaic vestiges and associations, perhaps most notably in the dress and accoutrements of the triumphator (such as the red minium, the toga picta, and the tunica palmata). How authentically archaic these features were is a matter of debate, but the archaic atmosphere they added to the ritual was evidently important to the Romans. Exploring the triumph - and other such rituals - can therefore offer a window into aspects of Roman society, although not directly into archaic society, as Momigliano believed. As with a number of other rituals, such as the Lupercalia, the triumph appears to have been an early institution, which Romans of the late Republic could deploy for very contemporary purposes. The ways in which this was done can be illuminating.

Despite these problems, Momigliano's point about the value of the study of early Rome remains valid. There exists no significant foundation of reliable evidence, and there is no scholarly consensus on the historical value of the evidence which does survive, on the uses to which that evidence can be put, or the sorts of questions that it can answer. Anyone who wishes to study the period, therefore, must first draw their own conclusions about the value of the evidence and the specific questions that it is able to address, and they must first decide upon their own methodology. Given the differences in the nature of the various types of evidence that is available, as well as the extent of the debate about the value of it all, the range of possible approaches is considerable. And, as noted earlier, when it comes to a topic like politics and power, the literary evidence in particular inevitably remains central to any discussion. While not every paper in this collection addresses the problems with that evidence directly (the focus is power and politics, after all, and not methodology), each contributor's assessment should be discernible from their own handling of it.

This collection begins, appropriately enough, with M. Trundle's discussion of the emergence of historical consciousness at Rome, the contexts in which that took place, and the factors that may have influenced it. Next comes R. T. Ridley's paper, which explores the themes and developments in scholarship on Lars Porsenna, the king of Clusium, from the Renaissance to the present day. The questions pursued in both these papers help to illustrate and expand upon some of the problems with the literary sources and their handling that have been raised in this introduction. For those new to the study of early Rome it may come as a surprise that neither of these papers attempts to answer a discrete question about 'what really happened'. Instead, both papers are focused on the historiography on the period, both ancient and modern, and how that shapes our understanding. The debate and interpretation are just as important as the evidence itself.

The four papers which follow all focus on matters connected with the priests and magistrates of the early Roman state, and the development of 
the state and the republican constitution: first, F. Glinister discusses the rex sacrorum, a priesthood which, Glinister argues, actually emerged during the regal period, and not afterwards, as the Romans themselves believed; next, J. H. Richardson explores the sudden appearance of the Roman nobility with the advent of the Republic, and the problems of the early consular fasti; third, F. K. Drogula looks at the tribunes of the plebs which, he argues, were the primary civic magistrates of the early Republic (and not the consuls, as the tradition may seem to imply); fourth is J. Armstrong's paper on the development of imperium and the shifting nature of military command in early Rome. All four of these papers attempt to make sense of the literary evidence, but do so using a range of different approaches and methodologies. All four, to varying degrees, challenge the basic account of events that is found in the writings of the Romans themselves, and several seek to replace that account with something else. Some, like Richardson, are deeply sceptical about the historicity of the evidence, while others, like Glinister, are much more optimistic. All, however, are unified in attempting to find a coherent and logical way to account for the evidence and, where possible, in using that evidence to say something about early Roman society.

This group of papers is followed by G. Bradley's discussion of migration and social mobility and the influence these aspects of archaic society had on early Rome and Rome's early institutions. One of those institutions was the gens, and C. Bartlett traces something of its decline in his study of intestate inheritance. In both papers, the question of the nature and importance of the gens is addressed, although the approach taken in each is very different. Bradley adopts a broader paradigm, drawn in part from sociology and anthropology, in an attempt to make sense of the often contradictory evidence for mobility within early Roman and central Italian society. Bartlett, in contrast, looks at the later legal tradition for the Roman gens and searches this evidence for clues to the gens' overall development in Roman society. Both of these papers therefore go beyond the problematic evidence for early Rome and seek to find more secure parallels elsewhere to buttress their arguments.

As Rome's influence and territory expanded, the Romans inevitably had to develop ways and means of dealing with neighbouring peoples, friends and allies on the one hand, and enemies on the other. O. Stewart's paper looks at the Roman practice of granting different forms of citizenship (that is, citizenship with, or without, the vote) to nearby states, and considers what may have led the Romans to give the vote to some but withhold it from others. M. Helm pursues related themes in his paper on Rome's relationship with her allies in the fourth century BC. Both contributions tackle questions which verge on the 'historical' period. Although the advent of history writing at Rome was still a century away, the late fourth century is a period for which, it is usually maintained, more evidence was available to Rome's first historians. As a result, this is a period for which significant parts of the evidence are generally viewed as 
more trustworthy, although the evidence still needs to be handed with significant caution, as the approach and conclusions in both papers make clear.

Finally, C. J. Smith returns to the question of evidence, and offers a number of suggestions about the nature and future of the field of early Roman studies. While he acknowledges the significant problems with the literary sources, Smith argues that within the totality of the available evidence - most notably including the archaeological evidence - a viable, if somewhat hazy, image of early Rome is recoverable. And indeed, given the ever-increasing knowledge of the archaeology of Rome, that image looks set to become clearer in the future.

University of Auckland

JEREMY ARMSTRONG js.armstrong@auckland.ac.nz

Massey University

J. H. RICHARDSON

J.H.Richardson@massey.ac.nz

\section{BIBLIOGRAPHY}

Ammerman, A. J. and D. Filippi (2004), 'Dal Tevere all'Argileto: nuove osservazioni', Bullettino della Commissione Archeologica Comunale di Roma 105, 7-28.

Ampolo, C. (2013), 'Il problema delle origini di Roma rivisitato: concordismo, ipertradizionalismo acritico, contesti. I', $A S N P$ s. 5, 5/1, 217-84, 441-7.

Badian, E. (1966), 'The Early Historians', in T. A. Dorey (ed.), Latin Historians. 1-38. London.

Becker, J. A., M. Mogetta, and N. Terrenato (2009), 'A New Plan for an Ancient Italian City: Gabii Revealed', AJA 113.4, 629-42.

Bietti Sestieri, A. M. (2000), 'The Role of Archaeological and Historical Data in the Reconstruction of Italian Protohistory', in D. Ridgway et al. (eds), Ancient Italy and its Mediterranean Setting: Studies in Honour of Ellen Macnamara. 13-31. London.

Bispham, E. H. and T. J. Cornell (2013), 'Q. Fabius Pictor', in T. J. Cornell et al. (eds), The Fragments of the Roman Historians, Volume I: Introduction. 160-78. Oxford.

Briscoe, J. (2013), 'Cn. Gellius', in T. J. Cornell et al. (eds), The Fragments of the Roman Historians, Volume I: Introduction. 252-5. Oxford.

Brock, A. L. and N. Terrenato (2016), 'Rome in the Bronze Age: Late Second-Millennium BC Radiocarbon Dates from the Forum Boarium', Antiquity 90, 654-64.

Broughton, T. R. S. (1951), The Magistrates of the Roman Republic, Volume I: 509 B.C.-100 B.C. New York. 
Carandini, A. (2011), Rome: Day One, translated by S. Sartarelli. Princeton.

Cornell, T. J. (1995), The Beginnings of Rome: Italy and Rome from the Bronze Age to the Punic Wars (c. 1000-264 BC). London.

— (2005), 'The Value of the Literary Tradition Concerning Archaic Rome', in K. A. Raaflaub (ed.), Social Struggles in Archaic Rome: New Perspectives on the Conflict of the Orders, 2nd edn. 47-74. Malden, MA.

Crawford, M. H. (1974), Roman Republican Coinage, 2 vols. Cambridge.

Cristofani, M. (ed.) (1990), La grande Roma dei Tarquini: catalogo della mostra. Rome.

Feeney, D. (2007), Caesar's Calendar: Ancient Time and the Beginnings of History. Berkeley.

Flaig, E. (2003), Ritualisierte Politik: Zeichen, Gesten und Herrschaft im Alten Rom. Göttingen.

Forsythe, G. (1999), Livy and Early Rome: A Study in Historical Method and Judgment. Stuttgart.

— (2005), A Critical History of Early Rome, from Prehistory to the First Punic War. Berkeley.

Frier, B. W. (1999), Libri Annales Pontificum Maximorum: The Origins of the Annalistic Tradition, 2nd edn. Ann Arbor.

Fulminante, F. (2014), The Urbanisation of Rome and Latium Vetus: From the Bronze Age to the Archaic Era. Cambridge.

Gabba, E. (1991), Dionysius and The History of Archaic Rome. Berkeley. Hall, J. M. (2014), Artifact \& Artifice: Classical Archaeology and the Ancient Historian. Chicago.

Hölkeskamp, K.-J. (2010), Reconstructing the Roman Republic: An Ancient Political Culture and Modern Research, translated by H. Heitmann-Gordon. Princeton.

Hopkins, J. (2016), The Genesis of Roman Architecture. New Haven.

Jones, L. (2016), 'Memory, Nostalgia and the Roman Home', in M. García Morcillo, J. H. Richardson, and F. Santangelo (eds), Ruin or Renewal? Places and the Transformation of Memory in the City of Rome. 183-211. Rome.

Momigliano, A. (1963), 'An Interim Report on the Origins of Rome', JRS $53,95-121$.

Ogilvie, R. M. (1965), A Commentary on Livy, Books 1-5. Oxford.

Pobjoy, M. P. (2013), 'L. Calpurnius Piso Frugi', in T. J. Cornell et al. (eds), The Fragments of the Roman Historians, Volume I: Introduction. 230-9. Oxford.

Poucet, J. (2000), Les Rois de Rome: Tradition et histoire. Louvainla-Neuve.

Raaflaub, K. A. (2005), 'The Conflict of the Orders in Archaic Rome: A Comprehensive and Comparative Approach', in K. A. Raaflaub (ed.), Social Struggles in Archaic Rome: New Perspectives on the Conflict of the Orders, 2nd edn. 1-46. Malden, MA. 
Rich, J. W. (2013), 'Annales Maximi', in T. J. Cornell et al. (eds), The Fragments of the Roman Historians, Volume I: Introduction. 141-59. Oxford.

Richardson, J. H. (2014), “Firsts” and the Historians of Rome', Historia $63,17-37$.

Sisani, S. (2004), 'Il foro romano', in F. Coarelli (ed.), Gli scavi di Roma, 1878-1921. 59-68. Rome.

Smith, C. J. (2011), 'The Magistrates of the Early Roman Republic', in H. Beck, A. Duplá, M. Jehne, and F. Pina Polo (eds), Consuls and Res Publica: Holding High Office in the Roman Republic. 19-40. Cambridge.

Terrenato, N. (2001), 'The Auditorium Site in Rome and the Origins of the Villa', JRA 14, 5-32.

Ungern-Sternberg, J. von (2005), "The Formation of the "Annalistic Tradition": The Example of the Decemvirate', in K. A. Raaflaub (ed.), Social Struggles in Archaic Rome: New Perspectives on the Conflict of the Orders, 2nd edn. 75-97. Malden, MA.

Winter, N. A., I. Iliopoulos, and A. J. Ammerman (2009), 'New Light on the Production of Decorated Roofs of the 6th C. B.C. at Sites in and Around Rome', JRA 22, 6-28.

Wiseman, T. P. (1979), Clio's Cosmetics: Three Studies in Greco-Roman Literature. Leicester.

(1993), 'Lying Historians: Seven Types of Mendacity', in C. Gill and T. P. Wiseman (eds), Lies and Fiction in the Ancient World. 122-46. Exeter.

(1995), Remus: A Roman Myth. Cambridge. (1998), Roman Drama and Roman History. Exeter. (2001), 'Reading Carandini', JRS 91, 182-93. (2004-2006), 'Andrea Carandini and Roma Quadrata', Accordia Research Papers 10, 103-25.

— (2008), Unwritten Rome. Exeter.

(2013), 'The Palatine, from Evander to Elagabalus', JRS 103, 234-68. 